〈報 告〉

\title{
東日本大震災後の避難所に抢いて発生した A 型インフルエンザアウトブレイク事例
}

\author{
遠藤 史郎 ${ }^{1)} \cdot$ 徳田 浩-1) $\cdot$ 八田 益充 ${ }^{1)} \cdot$ 國島 広之 ${ }^{2)} \cdot$ 猪俣 真也 ${ }^{1)}$ \\ 石橋 令臣 ${ }^{1)} \cdot$ 新井 和明 3$) \cdot$ 具 芳明 2$) \cdot$ 青柳 哲史 ${ }^{1)} \cdot$ 山田 充啓 ${ }^{2}$

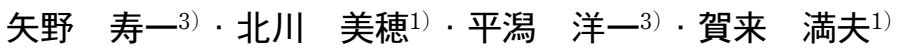

\section{Outbreak of Influenza A at the Refuge Center after the East Japan Great Earthquake Disaster}

Shiro Endo ${ }^{1)}$, Koichi TokudA ${ }^{1)}$, Masumitsu Hatta ${ }^{1)}$, Hiroyuki Kunishima ${ }^{2)}$, Shinya Inomata ${ }^{1)}$,

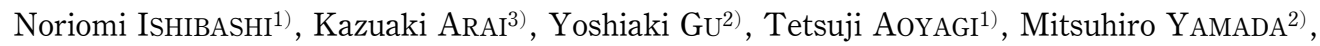
Hisakazu $\mathrm{YANO}^{3)}$, Miho KITAGAwA ${ }^{1)}$, Yoichi HiRAKATA ${ }^{3)}$ and Mitsuo KAKU ${ }^{1)}$

1) Department of Infection Control and Laboratory Diagnostics, Internal Medicine, 2) Department of Regional Cooperation for Infectious Diseases,

3) Department of Clinical Microbiology with Epidemiological Research \& Management and Analysis of Infectious Diseases, Tohoku University Graduate School of Medicine

( 2011 年 7 月 22 日 受付 $\cdot 2011$ 年 10 月 26 日 受理)

要 旨

2011 年 3 月 11 日の東日本大震災に伴う宮城県名取市館腰避難所に挨いてインフルエンザアウ トブレイクが発生した。同避難所では 200 名の避難者が共同生活を営んでおり，40\%が 65 歳以上 の高齢者であった。初発例発生から 5 日目の 4 月 8 日当避難所の巡回診療を行っていた名取市医 師会会長よりインフルエンザアウトブレイクに対する介入要請があり, 対応策構築のために同避難 所へ介入した. 介入時既に, non-pharmaceutical interventions: NPI として, 発症者全員の隔離が 行われていたが，隔離以外の手指衛生をはじめとするNPI は十分には行われていなかった，一方 で，計 22 名への予防投与が行われていた。 したがって，NPI を中心した基本的対策の強化 （i : マスク着用率の向上, ii ：手指衛生の適切な実施の啓発, iii : 換気の実施, iv : 有症状者の 探知抢よび発症者家族のモニタリング強化， $\mathrm{v}$ ：発症者の隔離）を現場スタッフと確認し，一方， 現場医師と予防投与は基本的対策を徹底したうえで，なお，感染が拡大した場合のみ考慮すべき対 策であること，また，その範囲・適応などに関して協議した４月 13 日，2 度目の介入を行い新 規発症者は 18 日の 1 人を最後に終息した，避難所に抢けるインフルエンザアウトブレイクは過去 にも報告が少なく, 初めての経験であった，予防投与はあくまで補助的な方策であり，アウトブレ イクの規模や感染リスクを考慮し, さらにNPI の強化徹底を行った上で行うことが必要であると 考えられた.

Key words : インフルエンザ, アウトブレイク, non-pharmaceutical interventions, 予防投与, 災 害医療

はじめに

2011 年 3 月 11 日, マグニチュード 9.0 の巨大地震が 発生し, 宮城県内では最大 30 万人が避難所生活を余儀

東北大学大学院医学系研究科 ${ }^{1)}$ 内科病態学講座感染制御 - 検 查診断学分野, ${ }^{2}$ 感染症診療地域連携講座, ${ }^{3}$ 臨床微生物解析 治療学講座
なくされた，避難所には収容可能人数をはるかに超える 人々が避難した．避難所には学校や体育館などが指定さ れているものの, 避難所に抢いて長期間の生活を行うこ とは想定されていない。ささらに，電気・水道・通信手段 などのライフラインが寸断されたこともあり，多くの避 難所では人口密度の高い状況下での集団生活を行うこと 
を余儀なくされた．このような避難所環境は飛沫感染や 接触感染を感染経路とする感染症が蔓延しやすいことが 危惧されていた。震災後 1 ヶ月が経過した 4 月 7 日, 宮城県名取市にある館腰小学校の体育館を利用した避難 所にてインフルエンザのアウトブレイクがあり, 同市医 師会上り東北大学大学院感染制御 - 検查診断学分野教室 に介入要請があったため現地を訪問の上, 対応支援を実 施した. 物資やライフラインに制限のある大災害後の避 難所に抢けるインフルエンザ感染対策にはガイドライン 等がなく, 対策を構築する上で不明な点も多い. 今回, 我々は東日本大震災に伴う避難所に拀いて発生した A 型インフルエンザアウトブレイク事例を経験したので報 告する.

\section{事例概要 (材料方法, 結果含む)}

\section{1. 避難所の概要および健康管理体制}

当避難所は津波により大きな被害を受けた宮城県南部 沿岸の名取市(図 1)にある市立小学校の体育館を利用し た避難所である。幸い同小学校周辺は津波の被害から免 れていた，当避難所施設内の見取り図を図 2 に示す. 避 難者数 200 名, $40 \%$ が 65 歳以上の高齢者であった. 食 事の配給は 1 日 2 回, 上下水道は既に復旧しており, 流水による手洗いが可能な状況であった。 一方, 健康管 理は名取市医師会・名取市保健センターによる定期巡 回，山梨県保健師の常駐により行われていた。

\section{2. 介入の経緯}

東北大学大学院感染制御 ·検査診断学分野教室は震災 翌日から, 地域診療支援チーム扔よび大学病院診療支援 チームを組織し, 震災後の感染症診療・感染症対策を行 っていた。震災後 6 日目より, 被害の大きかった宮城 県沿岸部の避難所を巡回し，宮城県疾病感染症対策室と
連携を取り，実際の現場の状況をもとに「避難所におけ る感染対策リスクアセスメント」を行い，得られた情報 をもとに「避難所における感染対策マニュアル」や「抗 インフルエンザ薬の予防投与について」などの資料を作 成し，行政と連携の上，広く避難所へ配布するとともに ホームページでも公開し，避難所に抢減染対策指導 とバックアップを行っていた ${ }^{1)}$. 震災発生から約 1 ヶ月 が経過した 4 月 7 日, 同市医師会会長より当避難所に 抒いてインフルエンザがアウトブレイクしているとの連 絡があり，状況確認抢よびインフルエンザアウトブレイ

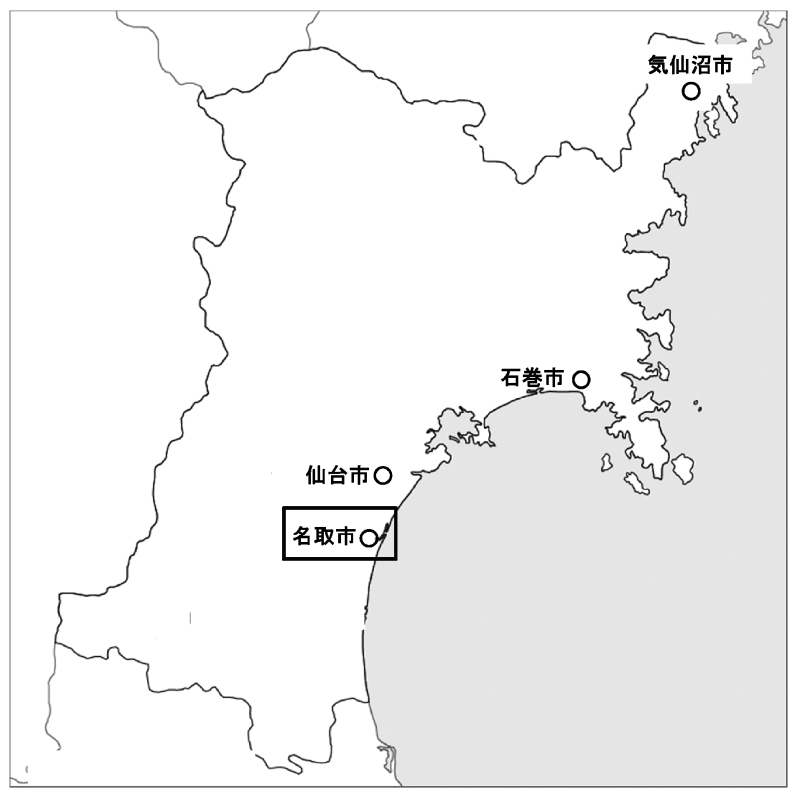

図 1 宮城県名取市の位置

沿岸沿いにある。津波により甚大な被害を受けた。館腰避 難所は津波の被害から免れた地域にある.

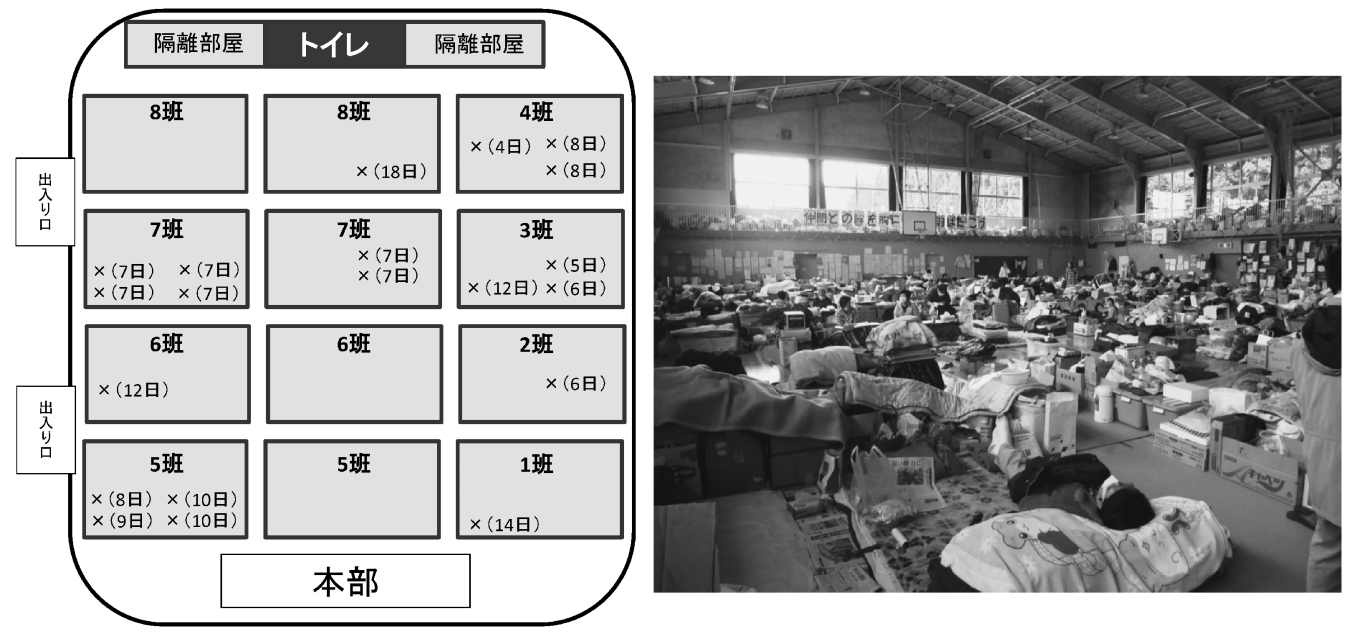

図 2 避難所内の見取り図および発症者の位置関係と避難所内の写真 ×は発症者，（）内は発症日を示す 
クに対する対応策構築のため, 翌 4 月 8 日同避難所に 介入した。

\section{3. 介入時の状況 (4 月 8 日)}

既に 13 人の発症者が確認されていた. 発症者全員 (状況に応じて家族も含めた)の隔離部屋への移動, 発症 者と長時間隣接していた濃厚接触者, 計 22 人への予防 投与が行われていた。 一方, 手指衛生に用いるアルコー ル製剤の使用状況は開封日と残量から推測すると不十分 であり，咳エチケットの遵守率もマスク装着率を観察し た限りでは不十分である様子がうかがわれた，また，換 気に関しては，体育館の構造上は換気可能であったもの の，寒さのため十分に行われている状況ではなかった。 インフルエンザ様症状 (発熱, 呼吸器症状, 全身倦㤐感 などの不定愁訴）を有する者の早期の探知，モニタリン グは常駐保健師が中心となり積極的に行われていた.

\section{4. 介入時の提案}

マスク，アルコール製剤の供給量が充分であったにも かかわらず，その使用状況が不十分であることが推測さ れたことから，i ）インフルエンザ様症状者を中心(濃厚 接触者も含む) としたマスクの着用率の向上, ii ) 流水を 用いた手洗いまたはアルコール製剤を用いた手指衛生の 適切な実施の啓発，iii) 可能な限りの換気の実施，iv）イ ンフルエンザ様症状者の探知および発症者家族のモ二タ リング強化, v ) 発症者 (状況に応じて家族などの濃厚接 触者を含む)の隔離などの基本的対策の徹底を避難所常 駐の保健師と確認した。 また，同医師会長と現段階での 対策として，避難所の過密な状況を考慮したうえで， I : 基本的対策は i )-v )が中心であること，II：予防
投与は，基本的対策を徹底したうえで感染拡大が制御困 難な場合のみ考慮すべき対策であること， III：予防投与 を行う場合の対象者の範囲および適応などに関して協議 した。また，その適応に関しては国立感染症研究所 ${ }^{2} や$ $\mathrm{CDC}^{3)}$ などのガイドラインを参考とした.

\section{5. 介入後の経過}

症例定義を「同避難所で生活をしていた者の中で 4 月 4 日以降にインフルエンザ抗原陽性が確認された 者, または, インフルエンザ様症状を有し, 臨床的にイ ンフルエンザと診断された者」と定めた．新規症例は 9 日以降減少し，11日には一旦，0人となったが，12 日 新規発症者が 2 人出たため, 13 日に再度現場へ介入し た(図 3). 前回介入時 (8日) と比較してマスク着用率, アルコール製剤の使用率向上，1 日数回の換気の実施， 隔離の実施などの基本的対策が徹底されていた．新規発 症者は 14 日 1 人, 18 日 1 人で終息した. 発症者の中 に, 重症化例はなかった。 また, 医療従事者の発症も確 認されなかった．本事例に抢ける発症者全員の詳細を表 に示す.

\section{考察}

避難所のような閉鎖なたは半閉鎖された環境における インフルエンザ対策としては，地域のインフルエンザ流 行状況を考慮し，基本的対策である non-pharmaceutical interventions: NPI（手指衛生，咳エチケット，換気，隔 離など)を実施し，さらにインフルエンザ様症状を有す る者を早期に探知し, 迅速検査を行い, 発症者が出た 場合には濃厚接触者をモニタリングすることが重要と

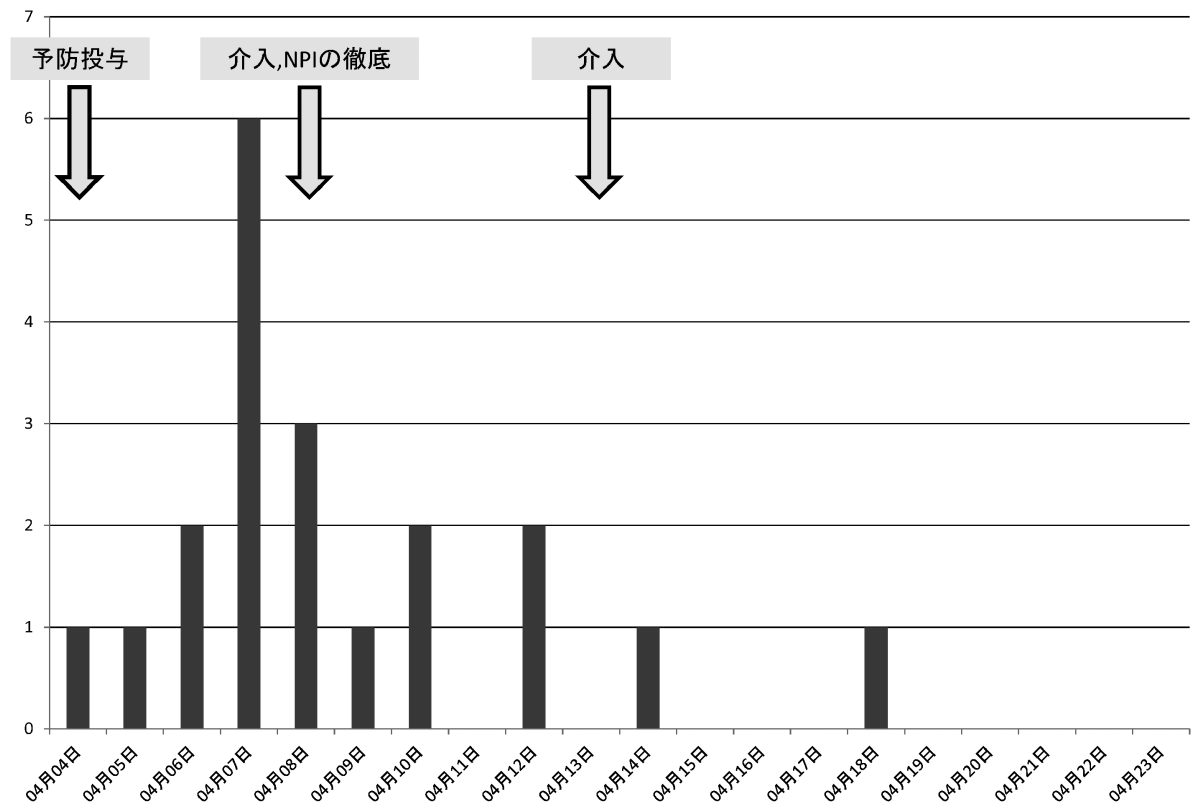

図 3 館腰避難所における A 型インフルエンザ流行曲線 
表 本事例における発症者全員の詳細

\begin{tabular}{|c|c|c|c|c|c|c|c|c|}
\hline 年齢 & 性 & 班 & 発症日 & 最高体温 & 発熱以外のインフルエンザ様症状 & 迅速抗原 & ワクチン接種歴 & 基礎疾患 \\
\hline 42 & 男 & 4 & $4 / 4$ & 不明 & 不明 & A 陽性 & 不明 & \\
\hline 47 & 女※ & 3 & $4 / 5$ & 38.9 & 頭痛, 咳, 咽頭痛 & A 陽性 & 不明 & \\
\hline 80 & 男 & 2 & $4 / 6$ & 39.4 & 頭痛 & 陰性 & 不明 & \\
\hline 70 & 女 & 3 & $4 / 6$ & 38.1 & 鼻汁, 倦念感 & A 陽性 & 不明 & 高血圧 \\
\hline 11 & 男※ & 7 & $4 / 7$ & 38.5 & - & 陰性 & 不明 & \\
\hline 63 & 女 & 7 & $4 / 7$ & 37.9 & 鼻汁, 咽頭痛 & A 陽性 & 不明 & \\
\hline 56 & 男* & 11 & $4 / 7$ & 39.9 & 咳 & A 陽性 & 不明 & 陳旧性肺結核 \\
\hline 49 & 女* & 11 & $4 / 7$ & 37.1 & - & 未施行 & + & \\
\hline 7 & 男* & 11 & $4 / 7$ & 37.7 & 鼻汁, くしゃみ & 未施行 & + & \\
\hline 49 & 女 & 11 & $4 / 7$ & 38.5 & 咳, 関節痛 & A 陽性 & 不明 & \\
\hline 72 & 女 & 9 & $4 / 8$ & 37.2 & 鼻汁, 咳, 痰 & A 陽性 & + & 自律神経失調症 \\
\hline 40 & 女 & 4 & $4 / 8$ & 38.5 & 咳, 咽頭痛, 倦怠感 & A 陽性 & 不明 & うつ病 \\
\hline 36 & 男 & 4 & $4 / 8$ & 37.3 & 鼻汁, 倦怠感 & A 陽性 & 不明 & \\
\hline 17 & 女 & 9 & $4 / 9$ & 38 & - & A 陽性 & 不明 & \\
\hline 40 & 女^ & 9 & $4 / 10$ & 40.9 & 咳, 痰, 咽頭痛 & A 陽性 & 不明 & \\
\hline 40 & 男 & 9 & $4 / 10$ & 37.4 & 鼻汁, 咽頭痛 & 陰性 & 不明 & \\
\hline 60 & 男 & 10 & $4 / 12$ & 38.1 & 頭痛, 鼻汁 & A 陽性 & 不明 & 糖尿病, 高血圧 \\
\hline 44 & 女 & 3 & $4 / 12$ & 37.4 & 鼻汁 & A 陽性 & 不明 & \\
\hline 62 & 女 & 1 & $4 / 14$ & 37.8 & - & A 陽性 & 不明 & 脳血管疾患 \\
\hline 59 & 女 & 8 & $4 / 18$ & 38.1 & 倦怠感 & A 陽性 & 不明 & \\
\hline
\end{tabular}

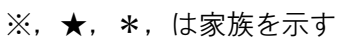

なる4).

本アウトブレイクが発生した 2011 年第 14 週の名取 市を管轄している塩釜保健所管内におけるインフルエン ザは定点あたりの報告数で 0.93 (http://www.ihe.pref. miyagi.jp/cgi-bin/survey/kwrep)であり，流行を認める 状況ではなかった，定点あたりの報告数は, 避難所周囲 は比較的震災の影響が少ない地域であったこと, 震災発 生からすでに 1 ケ月が経過していたことから，少なく とも避難所近隣の地域においては, ある程度機能してい たと考えられた。2 011 年第 14 週は東日本大震災から 1 ヶ月が経過した時点であり, 交通も復旧し始めた時期で あった．したがって, 日本全国から多数の支援者が宮城 県を訪れる(物質の搬入などに伴い，多くの人が避難所 に出入りしている）という状況があり，また，避難所で 生活している人々も，日中は自宅付近へ戻ったりと外出 の機会が多くなっている状況であった。このような状況 は市中でのインフルエンザ感染の機会を増加させうる. したがって，外部からの持ち込みも念頭に置き，明らか な地域流行がない場合でも，避難所においてはインフル エンザのアウトブレイクが起こり得ることが示唆された.

インフルエンザがアウトブレイクした場合の対策とし て，大きく分けて I ) non-pharmaceutical interventions: NPI (手指衛生, 咳エチケット, 換気, 隔離など) と, II ) pharmaceutical interventions: PI（抗インフルエンザ 薬を用いた対策)に大別される.アウトブレイク時の状 況や利用可能な医療資源によっては I ) と II)を効果的に
組み合わせて対策を行っていく必要があるものの，ま ず，行うべき対策は手指衛生や咳エチケットなどの NPI を中心とした対策である5)。また，NPI を一定期 間，徹底・強化することが重要であると報告されてい る6). Cowling BJ らが閉鎖または半閉鎖的な環境にお いても，手指衛生とマスクの着用がインフルエンザ感染 症の伝播抑制に有効であったと報告しているように7), NPI の有効性は他にも多数検証され報告8 10) されてい る.

同避難所における初発例は 4 月 4 日避難所を退所し た 42 歳男性であったと考えられた。本症例は避難所で の生活中は発熱などのインフルエンザ様症状は確認され ていなかったものの，退所後に悪寒を認め自発的に近医 を受診し，A 型インフルエンザ抗原陽性が判明した. 本初発例で特筆すべきは，その情報がリアルタイムに避 難所抢よび保健センターに伝えられ，医療機関，避難 所，行政で情報の共有化が行われていたことである. Jin Z ら ${ }^{11)}$ の報告にもあるように情報の共有化はアウト ブレイク対応に打ける有用な手段であることから，本事 例に抢ける各連携機関の情報の共有化は非常に有用であ ったと考えられた。

震災後 1 ケ月が経過しても上下水道の復旧が遅れて いた避難所が多い中，幸いにも同避難所は流水による手 洗いが可能であったことは手指衛生上大きなメリットと なった。アルコール製剤を用いた手指衛生の啓発・徹底 を常駐保健師に助言した。具体例として，アルコール製 


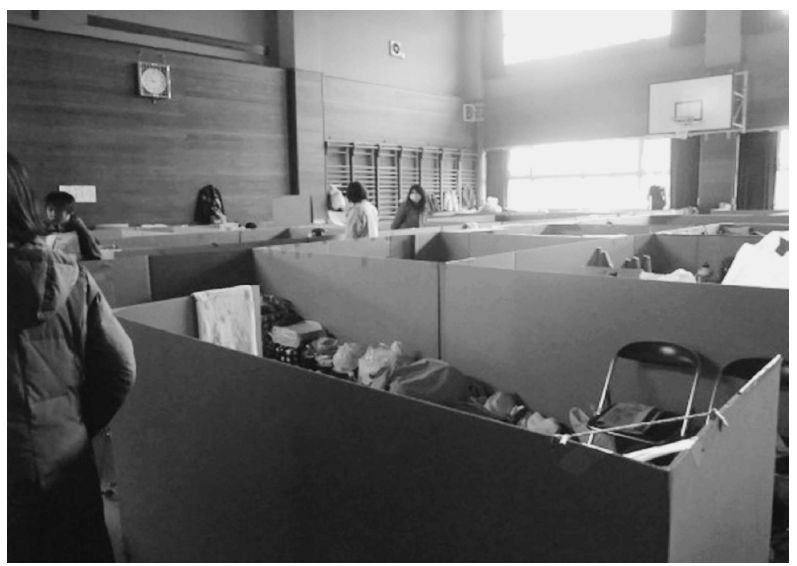

写真 1 避難所における段ボール等を利用した仕切り版の 導入例

$100 \mathrm{~cm}$ 程度の高さあり．物資が手に入れば飛沫 感染対策の一役を担うと思われる。

剤の使用頻度向上のために, 各出入り口のみならず可能 であれば班ごとの設置も提案した，咳エチケットに関す る有効性は多数報告されている12,13)。しかし，その遵守 率の向上方法に関しては述べられていない。本事例で は，ポスターなどによる啓発を行っていたが，掲示板た けでの効果は十分とは言えず，現場保健師が個別にマス クの着用を促すことがマスク着用率向上に最も寄与して いた。 また，我々が実際に現場に介入したことにより，

「何か大変なことが起きているのでは?」という危機意 識が避難所で自然に芽生えたことも，介入後のマスクの 着用率の向上に寄与したものと考えられた。 また，隣人 への飛沫の拡散を防止する対策として，いくつかの避難 所では比較的早期から仕切り版の導入 (写真 1)が行われ て抢り，飛沫感染対策の一部として有効であると考えら れた。しかし，同避難所ではその導入はなく，飛沫を介 した隣人への感染が比較的容易な状況であった。地域の コミュニティーごとの避難所生活を考えた場合，隣人の 顔が見えることが避難中の安堵感につながることがあ り，同避難所でもこのような理由や，仕切り版に用いる 物資の調達不足などのために導入が困難となっていた.

換気に関しては，同避難所では構造上換気は可能で あるが，気温の低さ(名取市の 4 月 5 日最低気温： $\left.-2.4^{\circ} \mathrm{C}\right)$, 燃料不足による暖房制限により，現実的には 充分に行うことは困難であった。また，隔離の有効性に 関しても多くの報告がある8,10)。避難所においては隔離 スペースの確保の問題，また，実際隔離した場合，健康 状態を適切に観察するためのマンパワーがあるかどうか などの問題により，隔離が困難な場合も多い。同避難所 では発症者専用の隔離部屋があり（写真 2)，また，隔離 部屋に收容された人の健康管理も適切に行われ，本アウ トブレイクの終息に大きく貢献したと考えられた.

一方，予防投与に関しては，オセルタミビルの効果が

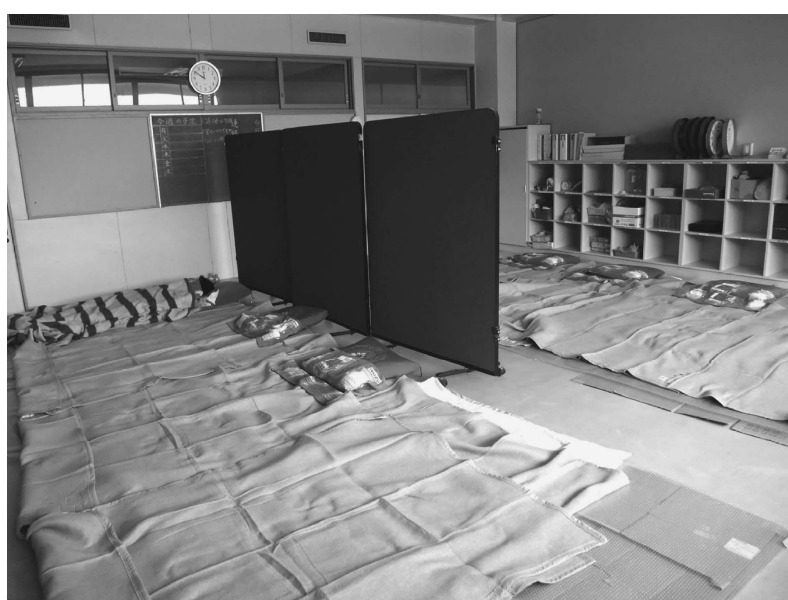

写真 2 館腰避難所の隔離部屋

最大 10 名収容可能なスペースが確保されていた。

68-89\%，ザナミビルの効果は 72-82\% と予防投与自体 の有効性は認められている3)。 その対象者は濃厚接触 者 ${ }^{1,3)}$ (長時間隣接して $2 \mathrm{~m}$ 以内にいる人)の中で 65 歳以 上の高齢者や慢性心疾患, 慢性呼吸器疾患なぞを有して いる人であり，健康人は含まれていない。むしろ，副作 用や耐性化の点から健康な人への予防投与は控えるべき と報告されている2,14,15). 一方で従来の予防投与対象者 を拡大した ring prophylaxis が提唱されその有効性が報 告されているものの，予防投与自体の効果は発症者数の ピークを一時的に遅らせる時間稼ぎ的なものであり，最 終的な終息には予防投与以外の方法が必須であると報告 されている16). 本事例は介入時に既に計 31 人に対して 予防投与 (ring prophylaxis に近い形)が行われて抢り， アウトブレイクを疑った時点で，予防投与をどのタイミ ングで，どの範囲まで行うかは，議論の分かれるところ であるが，予防投与はあくまで補助的な方策であり，ア ウトブレイクの規模や感染リスクを考慮し，さらに NPI の強化徹底を行った上で検討すべきと思われる.

インフルエンザワクチンに関しては Prevention and Control of Influenza. MMWR 2008; 57 (RR-7): 1-59 に 扮いて, 発症予防に対する有效性も述べられているが, 本事例の発生時期が宮城県内のインフルエンザの流行期 ではなかったこと，また，ワクチン接種の効果発現まで の時間差などを考慮し, ワクチン接種を推奨する状況で はなかったと考えた。

避難所に打けるインフルエンザアウトブレイクは過去 にも報告が少なく，我々にとっても初めての経験であっ た。我々が介入した個々の対策が感染伝播防止にどの程 度寄与したかという明確なエビデンスを明示することは 困難であるが，NPI を中心とした個々の対策を組み合 わせることにより，結果として，介入後から発症者が減 少したこと，それに反比例してNPI を中心とした対策 
の遵守率が上昇したことから，有益な対策であったと考 えられた。

本アウトブレイクは医療保健従事者の献身的な活動, 関連機関における情報の共有化，および比較的早期の介 入により幸い重症化する症例なく終息できた.

謝 辞 : 本アウトブレイクの終息に御尽力頂いた，名取市医師 会丹野会長をはじめとする医師会の先生方, 名取市保健セン ター保健師の方々, 山梨県保健師の方々に心より深謝いたしま す.

利益相反について : 利益相反はない.

文献

1）東北感染症危機管理ネットワーク，東北大震㷋ホット ライン(医療従事者用) 各種情報 http://www.tohokuicnet.ac/shinsai/hotline_iryou.html

2）国立感染症研究所感染症情報センター, 東日本大震 災，被災地におけるインフルエンザ予防対策について http://idsc.nih.go.jp/earthquake2011/IDSC/20110322 infle.html

3) Fiore AE, Fry A, Shay D, Gubareva L, Bresee JS, Uyeki TM; Centers for Disease Control and Prevention (CDC). Antiviral agents for the treatment and chemoprophylaxis of influenza-recommendations of the Advisory Committee on Immunization Practices (ACIP). MMWR Recomm Rep. 2011; 60: 1-24.

4) Gaillat J, Dennetiere G, Raffin-Bru E, Valette M, Blanc MC. Summer influenza outbreak in a home for the elderly: application of preventive measures. J Hosp Infect. 2008; 70: 272-7.

5) Uyeki TM. $2009 \mathrm{H} 1 \mathrm{~N} 1$ virus transmission and outbreaks. N Engl J Med. 2010; 362: 2221-3.

6) Nuno M, Reichert TA, Chowell G, Gumel AB. Protecting residential care facilities from pandemic influenza. Proc Natl Acad Sci U S A. 2008; 105: 10625-30.

7) Cowling BJ, Chan KH, Fang VJ, Cheng CK, Fung RO, Wai $\mathrm{W}$, et al. Facemasks and hand hygiene to prevent influenza transmission in households: a cluster randomized trial. Ann Intern Med. 2009; 151: 437-46.
8) Mitchell T, Dee DL, Phares CR, Lipman HB, Gould LH, Kutty $\mathrm{P}$, et al. Non-pharmaceutical interventions during an outbreak of 2009 pandemic influenza A (H1N1) virus infection at a large public university, April-May 2009. Clin Infect Dis. 2011; 52: S138-45.

9) Merkel H, Stem AM, Cetron MS. Theodore E. Woodward award: non-pharmaceutical interventions employed by major American cities during the 1918-19 influenza pandemic. Trans Am Clin Climatol Assoc. 2008; 119: 129-38.

10) Loustalot F, Silk BJ, Gaither A, Shim T, Lamias M, Dawood F, et al. Household transmission of 2009 pandemic influenza A (H1N1) and nonpharmaceutical interventions among households of high school students in San Antonio, Texas. Clin Infect Dis. 2011; 52: S14653.

11) Jin Z, Zhang J, Song LP, Sun GQ, Kan J, Zhu H, Modelling and analysis on influenza A (H1N1) on networks. BMC Public Health. 2011; 11: S9.

12) Macintyre CR, Cauchemez S, Dwyer DE, Seale H, Cheung P, Browne G, et al. Face mask use and control of respiratory virus transmission in households. Emerg Infect Dis 2009; 15: 233-41.

13) Canini L, Andreoletti L, Ferrari P, D'Angelo R, Blanchon T, Lemaitre M, et al. Surgical mask to prevent influenza transmission in households: A cluster randomized trial. PLoS One. 2010; 5: e13998.

14) Update on oseltamivir-resistant pandemic A (H1N1) 2009 influenza virus: January 2010. Wkly Epidemiol Rec 2009; 85: 37-40.

15) Kitching A, Roche A, Balasegaram S, Heathcock R, Maguire H. Oseltamivir adherence and side effects among children in three London schools affected by influenza A(H1N1)v, May 2009-an internet-based crosssectional survey. Euro Surveill. 2009; 14: 19287.

16) Lee VJ, Yap J, Cook AR, Chen MI, Tay JK, Tan BH, et al. Oseltamivir ring prophylaxis for containment of 2009 H1N1 influenza outbreaks. N Engl J Med. 2010; 362: $2166-74$.

〔連絡先 : ₹980-8574 宮城県仙台市青葉区星陵町 1-1 東北大学医学部 3 号館 3 階 感染制御・検査診断学 分野医局 遠藤史郎

E-mail: ain@med.tohoku.ac.jp] 
Outbreak of Influenza A at the Refuge Center after the East Japan Great Earthquake Disaster

\author{
Shiro Endo ${ }^{1)}$, Koichi ToKuda ${ }^{1)}$, Masumitsu Hatta ${ }^{1)}$, Hiroyuki Kunishima ${ }^{2)}$, Shinya Inomata ${ }^{1)}$,

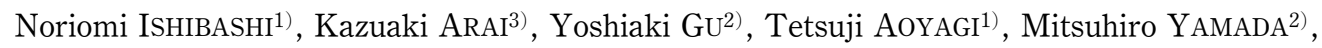 \\ Hisakazu Yano ${ }^{3)}$, Miho Kitagawa ${ }^{1)}$, Yoichi HiRAKata ${ }^{3)}$ and Mitsuo KaKU ${ }^{1)}$ \\ ${ }^{1)}$ Department of Infection Control and Laboratory Diagnostics, Internal Medicine, \\ ${ }^{2)}$ Department of Regional Cooperation for Infectious Diseases, \\ ${ }^{3}$ Department of Clinical Microbiology with Epidemiological Research \& Management and Analysis of \\ Infectious Diseases, Tohoku University Graduate School of Medicine
}

\begin{abstract}
An outbreak of influenza A occurred at the Tatekoshi Elementary School refuge center in Natori City, Miyagi Prefecture after the East Japan great earthquake disaster of March 11, 2011. Two hundred evacuees were housed at the refuge center of whom $40 \%$ were elderly people 65 years and older. Five days after the initial case on April 8, intervention was requested to deal with the influenza outbreak by the Chairperson of the Natori City Medical Association which was providing medical services at the refuge center. On April 8, we arrived to implement intervention measures, when non-pharmaceutical intervention (NPI) through the isolation of all individuals with early onset of influenza had been already been carried out. However, except for isolation, NPI including hand hygiene was not adequate. On the other hand, antiviral prophylaxis had been administered to 22 evacuees. Therefore, we focused on reinforcement of basic NPI measures including site staff education; improvement of the face mask wearing rate; emphasizing the importance of hand hygiene; implementation of adequate ventilation; aggressive detection of symptomatic individuals and monitoring family members for onset of symptoms; and isolation of persons at onset of infection. On the other hand, we also emphasized to the site physicians that antiviral prophylaxis was only effective if basic NPI measures were strictly enforced and that prophylaxis should only be considered if the outbreak expanded. On April 13, we made a second intervention visit. The last new case occurred on April 14. Influenza outbreak at a refuge center has not been previous reported and no guidelines have been established. Our experience suggests that prophylaxis should only be used to supplement NPI measures, which should be strengthened as the main intervention strategy, and should only be considered based on the extent of outbreak and patient risk factors.
\end{abstract}

Key words : influenza, outbreaks, non-pharmaceutical interventions, prophylaxis, disaster medicine 